\title{
Protecting Children from Their Families and Themselves: State Laws and the Constitution ${ }^{1}$
}

\author{
Robert A. Burt ${ }^{2}$ \\ Received June 18,1971
}

\begin{abstract}
State laws provide a variety of means to protect children from -self-inflicted or parentally-inflicted harm. In recent years, the Supreme Court has imposed stringent procedural requirements on juvenile delinquency laws. In the past year, however, the Court has refused to extend these procedural stringencies to analogous child-protective state laws. This article explores generally the rationale for court application, by constitutional mandate, of procedural safeguards to a broad range of child-protective legislation. The article suggests that some criminal-procedure rights are vitally important to protect children and their parents from inappropriate state interventions, but that wholesale application of all criminal rights, as if these laws were no different from criminal laws, unduly restricts proper application of these laws. Guidelines for determining what criminal rights should and should not be applied to child-protective legislation generally are suggested.
\end{abstract}

\section{CRIMINAL LAW AND CHILD ABUSE}

Criminal law procedures are considered inapplicable to child abuse and neglect laws in many states. In proceedings in which parents may be deprived of child custody for neglect or abuse (as opposed to criminal prosecution for such

\footnotetext{
${ }^{1}$ This article was previously published, in a slightly different format, in the Michigan Law Review (June 1971) under the title, "Forcing Protection on Children and Their Parents: The Impact of Wyman v. James."

${ }^{2}$ Associate Professor of Law, University of Michigan, Ann Arbor, Michigan. B.A., 1960, Princeton University; M.A., 1962, Oxford University; L.L.B., 1964, Yale University. Main interest is family law.
} 
conduct), parents are not guaranteed the presence of counsel, ${ }^{3}$ no "presumption of parental innocence" effectively favors retention of custody by the parent prior to final adjudication of abuse or neglect, ${ }^{4}$ the burden of proof at the trial is the civil "preponderance of the evidence" rather than the criminal standard, courts may rely on confidential information to determine the existence of neglect or abuse without giving confrontation opportunities, ${ }^{6}$ no "self-incrimination right" or Fourth Amendment "probable cause" requirement restrains courts from ordering pretrial physical or psychiatric examinations of parents or children to determine neglect or abuse. ${ }^{7}$

No state legislature has acted, or, at least, has admitted to acting, randomly to protect children. In all contested cases of alleged abuse or neglect, state laws require a court to engage in individualized inquiry. Ideally, this legislative command should lead a court to delve deeply into the psychological dynamics of any family coming before it, and to formulate a precise diagnostic view of the family against which it is possible to judge, first, whether serious harm is being worked on the child (though for severe physical injuries, this ground for psychological inquiry can be redundant), second, whether grave risks would attend removing the particular child from his otherwise harmful family, and third, whether treatment is available to be directed at this particular family

${ }^{3}$ See Illinois Juvenile Court Act, Ch. 37, 704-5, which assures appointed counsel for a child but not for his parents in such proceedings; to the same effect are Massachusetts Annot. Laws, Ch. 119, 29; Michigan Comp. Laws 712A.17; Mississippi Code 7185-08; New York Family Court Act 249, Virginia Laws 16.1-175. By contrast, California and Wisconsin permit, though neither state requires, appointment of counsel for parents in abuse or neglect proceedings. See Alameda County v. Espinoza, 243 C.A. 2d 534, 52 Cal Rptr. 480 (1966), Wisconsin Laws 48.25 (6).

${ }^{4}$ In 1967-68, the family courts in New York State disposed of 6347 child neglect petitions. Of those, 1759 children (or about 26\%) were removed from their homes pending final disposition of the petitions ( 286 children - or $4.5 \%$ of the total - were removed from their homes before any neglect petition was filed, and the remainder were removed after a petition was filed). Of these 1759 children, approximately $44 \%$ remained in a "short-term care" detention facility, pending disposition of the neglect petition, for more than 90 days. See Report of New York State Family Court, 1967-68. See Sections 1021-28 of the New York Family Court Act providing for temporary home removal of children both with and without court orders. See also Massachusetts Annot. Laws, Ch. 119 39A; Michigan Comp. Laws 712A.15, 722.571(a), Virginia Laws 16.1-166, 16.1-194.

${ }^{5}$ See New York Family Court Act 1046(b) (i); Illinois Juvenile Court Act, Ch. 37 704-6; Maryland Laws Ch. 26, 70-18; Texas Laws Ch. 43, 2332, Wisconsin Laws 48.25.

${ }^{6}$ See District of Columbia Code 11-15.85(b); New York Family Court Act, Ch. 37 705-1(2); Maryland Laws Ch. 26 70-14. Other states do, however, provide full confrontation rights in these proceedings. See California Code 4602; Massachusetts Annot. Laws Ch. 119, 24, Virginia Laws 16.1-162.

${ }^{7}$ See New York Family Court Act 251; Maryland Laws Ch. 26, 70-14; Virginia Laws 16.1-190; Wisconsin Laws 48.24. 
which would respond to its psychology. There is powerful support in the professional literature that any judgment to remove a child from his parents which is not thus firmly based on a clear view of family and individual dynamics is a wholly random intervention (Bowlby, 1965; Steele and Pollock, 1968; Terr and Watson, 1968; Gil, 1970). This professional view provides strong support to any judicial impulse toward requiring closer, more detailed attention to the individual characteristics of the particular family allegedly requiring state intervention. And for this purpose, constitutional "domestication" of court procedures, by imposing the "criminal label" on these proceedings, is obviously attractive.

But it would be a mistake for a court simply to adopt wholesale, via the Constitution, this professional view of the needs for precise diagnostic formulations. This is not simply because a court should disbelieve professional claims to precision. In the hands of its most skilled practitioners, there can be compelling clarity and precision in the use of psychological diagnostic tools. Nor should a court withhold allegiance from these views simply because of the obvious unavailability of such skilled practitioners, particularly in the low-status, low-paying child-protective agencies. If imprecision is inherent in the discipline or in its application to child abuse and neglect cases, that can be reason for a court to insist on greater care through procedural strictures in order to approach the ultima tely unattainable ideal.

A court must, however, consider these factors as reasons to abstain from imposing procedural strictures because there is obviously room for a quite reasonable, competing judgment that some strong pressure must be exerted on state officials to urge removal of children. Such pressure can be necessary precisely because of the imprecision and low skill of state child-protective personnel, which can lead to wrongful withholding of state intervention. There may be reasons to believe that state child abuse and neglect law administrators, acting even under current relatively lax procedures do not intervene into families as often as would be desirable in order to protect children. ${ }^{8}$ Professional uncertainty - either from inherent diagnostic imprecision or from unskilled imprecisions - can as readily lead to inaction as to excessive action. Moreover, the invisibility of most transactions between parent and child - particularly preschool children - is an intrinsic limiting factor on the possibility of any state intervention predicated on individualized inquiry, no matter how lax the standards of that inquiry (Dembitz, 1969). Thus, it is quite reasonable to assert that imposing added burdens on these proceedings is at least quixotic, if not harmful. But if there are "reasonable" arguments which a legislature can adduce to justify relaxed procedural standards for neglect and abuse laws, this fact

${ }^{8}$ Cf. New York Times, May 16, 1971, p. 57, col. 1. 
merely recasts the question for the courts. Are those competing arguments "reasonable enough" to justify rejecting the relevance of the criminal law analogues to these laws? Must, instead, the competing legislative arguments be "compelling"? Or, are these arguments "reasonable enough" that they are "compelling"?

Courts, it would seem, should resolve these questions - whether criminal law procedures must apply to these laws, whether legislative arguments to the contrary must be powerfully or merely plausibly persuasive - by consulting the Constitution. In the mystifying argot of the law, that means, in part, reasoning by analogy to past decisions. But like so much constitutional litigation, the available analogies point in opposing directions.

The most recent strong argument for imposing criminal procedures on abuse and neglect laws comes from the Supreme Court's decision in Gault. ${ }^{9}$ That case imposed criminal guarantees, such as right to appointed counsel and confrontation of opposing witnesses in open court, in juvenile proceedings. In so holding, the Court jettisoned the constitutional dogma of the preceding half-century which had maintained that since the purpose of the delinquency proceedings was not to punish but instead to protect the child, criminal law procedural protections were not needed. More than that, so the argument went, those guarantees would in troduce formalism and mistrust that would defeat the beneficent purposes of the proceedings. The Gault Court regarded this argument as a rhetorical pretense. It is unreal, the Court said, to claim that no punitive stigma accompanies an adjudication of delinquency, and even less real to pretend that juvenile courts have any substantial capacity to give beneficial treatment to those juveniles labeled and incarcerated as delinquents. ${ }^{10}$ Accordingly, Gault held, strict procedural guarantees are required to help match the reality of the juvenile court with its rhetoric.

The analogues between Gault and abuse and neglect laws are clear. Punitive stigma clearly accompanies a judgment that an "abusing" or "neglecting" parent should lose custody of his child, and it is quite likely that the child will view his removal - however benightedly and however much precisely because his parents have mistreated him - as a further punishment inflicted on him by omnipotent parents who now choose to desert him (Freud, 1965).

Further, the promise of beneficent treatment following home removal resounds hollowly against the hard reality of inadequate foster homes and understaffed, overcrowded long-term child detention facilities. It appears that the majority of children removed from their homes are eventually returned there (Fanshel, 1971), and in part because few resources are available for intensive

${ }^{9}$ In re Gault, 387 U.S. 1 (1967).

10387 U.S. at $14-31$. 
family therapy during this interim, it seems unlikely that this temporary removal works for the benefit either of the child or his family. From this recital, Gault appears to command by analogy that stringent procedural guarantees should be imposed on child abuse and neglect proceedings that would in effect make state intervention possible only in the most shocking, self-evident child abuse case.

But there is a contrary argument available. Gault gives procedural rights to a juvenile whose own conduct is in question in delinquency proceedings. In abuse and neglect proceedings, the child is seen as the alleged victim. His parents' conduct is in question. It can thus be argued that constitutionally grounded procedural rights are withheld from the parents in order to benefit the child, to protect him against his parents. The Supreme Court has recently given strong impetus to this argument. In Wyman vs. James, ${ }^{11}$ the Court rejected a welfare recipient's argument that caseworker home visits could not be made a compulsory part of welfare grants, unless a judicial search warrant were issued before each forced visit. The court ignored persuasive analogues to police searches in these welfare visits, and reached this result in substantial part by relying on the visit's "benevolent intent" and, in particular, on its alleged child-protective purposes. The Court stated that "the dependent child's needs are paramount, and only with hesitancy would we relegate those needs ... to a position secondary to what the mother claims as her rights." 12

The Wyman Court chose to ignore available evidence that the benevolent allegations of the welfare department were empty pretenses, that caseworkers were not viewed by welfare recipients as "friends in need" and were typically "badly trained or untrained" and "young and inexperienced." "13 The Court was similarly not troubled that the caseworker in the Wyman case itself had not asked and was not certain to see Mrs. James' child. ${ }^{14}$ The Wyman Court was content to assume that the visit was for the child's benefit, in the teeth of evidence similar to that which the Gault Court had found sufficient to disregard the juvenile court's protestations of benevolence and derivative claims of exemption from procedural stringencies.

It can be argued that Wyman is simply retrogressive, and that Gault's enlightened realism should prevail to impose criminalized procedures in abuse and neglect proceedings. But this argument is too glib. The promises of benefit in many abuse and neglect cases are scant. But is it clear that needed help is never provided under these laws, or that imposition of stringent procedural

11400 U.S. 304 (1971).

12400 U.S. at 318.

13400 U.S. at 323.

14 See Mr. Justice Marshall's dissent, 400 U.S. at 342. 
protections for parents would never work to withhold help from desperately needy children? "Better that ten guilty men go free than that one innocent be convicted" is the catchphrase invoked to justify stringent procedures in criminal cases. Is there an equivalent constitutional slogan that it is better that ten - or five, or one - abused children go undiscovered or unprotected so that one child - or five, or ten - could properly remain with his parents? Can a court calibrate these competing risks and benefits with sufficient certainty that it can justifiably override a different state legislative judgment?

In final analysis, constitutional exegesis yields no compelling answer to the question whether criminal procedures must, or need not, apply to child abuse laws. These laws touch values toward which the Court has traditionally been solicitous. The closeness of the criminal analogue in the operation of these laws and the hallowed status of the parent-child relation in our society ${ }^{15}$ cannot easily be overlooked. But neither can the Court ignore the potential for deeply hurtful abuse of authority of parent over child that our rootless, anomic society most particularly affords. Wyman looks to one direction, Gault to the other. Neither posture is a priori compelling.

But if it is, therefore, equally proper in logic for the Court to adopt either approach, it must be said that it is also equally improper that either be adopted. Thus the Court must - and can - seek a resolution of the competing solutions which to the greatest degree possible, avoids totally subordinating one principle to the other, and instead, to the greatest degree possible, works an accommodation of both.

\section{FAMILIES IN THE COURTS}

A closer examination of the operation of child abuse and neglect laws suggests some guidelines for the Court in attempting to accommodate "its" interests - in protecting traditional constitutional concerns in traditional fashion, by insisting on precise individualized judgments of the need for state intervention - with competing legislative interests against such attempts at precision. For this purpose, it will be useful to examine the New York legislature's experiences in 1969 and 1970, and to indulge some speculations on the psychological dynamics of those experiences.

In 1969 , the legislature hastily enacted a new child abuse law in response to a sensationally publicized murder of a three-year-old girl whom the New York Family Court had left in parental custody following a hearing on allegations of

15 Compare Meyer v. Nebraska, 262 U.S. 390,399 (1923), in which the court proclaimed that "to marry, establish a home and bring up children" were fundamental constitutional rights. 
abuse two months before her death. ${ }^{16}$ This new law was essentially intended to remove discretion from the Family Court in order to force state intervention. Two principle mechanisms were designed to accomplish this: any child found "abused" was required by the new law to be removed from home, ${ }^{17}$ thus abrogating traditional court dispositional discretion; and any child of an "adjudicated narcotics addict" was conclusively presumed to be "abused." 18 Enactment of this law might appear dramatically to reflect a "rescue fantasy" against which it is commonplace (though often ineffective) to warn individual caseworkers and judges who deal with abuse and neglect cases. John Bowlby (1965), in his classic work in separating children from parents, characterized this fantasy as follows (p. 140):

So long as caseworkers do not know the limitations (in removing children from their homes for whatever reason), but live, as some do, in the sentimental glamour of saving neglected children from wicked parents, they will act impetuously in relieving parents of their responsibilities and, by their actions, convey to the parents the belief that the child is far better off in the care of others. Only if the caseworker is mature enough and trained enough to respect even bad parents and to balance the less-evident long-term considerations against the manifest and perhaps urgent short-term ones, will she help the paren ts themselves and do a good turn to the child.

One important explanation regarding why "rescue" of the child from his "bad" parents may be no help at all to the child was stated this way by Bowlby (1965, p. 80):

The attachment of children to parents who, by all ordinary standards, are very bad is a never-ceasing source of wonder to those who seek to help them. Even when they are with kindly foster parents these children feel their roots to be in the homes where, perhaps, they have been neglected and ill-treated, and keenly resent criticisms directed against their parents. Efforts made to 'save' the child from his bad surroundings and to give him new standards are commonly of no avail, since it is his own parents who, for good or ill, he values and with whom he is identified. (This is a fact of critical importance when considering how best to help children who are living in intolerable conditions.)

But just as it was difficult for the New York Legislature, and for individual judges and caseworkers to perceive the depth of attachment which a child can have to very bad parents, it can be equally difficult for the legislature and for individual judges and caseworkers to acknowledge that some, or any, parents are

${ }^{16}$ See Committee on the Family Court and Family Law, "The Enactment of the Abused Child Law and Committee Findings as to Defects in the Law (Laws 1969, c. 264,") 34 Record of the Ass'n of the Bar of the City of N.Y. 347 (1969).

17 Ch. 264, 1969 McKinney's Sessions Laws for New York, 1022.

${ }^{18}$ Id, at 1012 . The New York Family Court subsequently struggled manfully to avoid this clear reading of the statute. See In Re John Children, 306 N.Y.S. 2d, 797 (1969). 
in fact very bad toward their children. And in some ways, symbolic if no other, the 1970 action of the New York Legislature - repealing the 1969 abuse law and restoring full discretion to the Family Court ${ }^{19}$ - was a rapid retreat away from its adamant stance a year earlier that mirrors a common state response in individual neglect and abuse cases - that is, swift, undifferentiated removal of an apparently hurt child from his parents followed after some official dallying and confusion by a return to the status quo ante, with at least some of the participants in the events sadder but not wiser (Terr and Watson, 1968).

The reasons for the possibility of misperceptions are clear, whether those misperceptions are an inappropriate "rescue fantasy" or a persistent refusal to accept the stark reality that a particular child must be removed from his parents. Though the explanation is easily accessible to common sense, approaching the matter through psychiatric terminology will be helpful (Freud, 1967; Gill, 1967; Schafer, 1967). In psychiatric language it is termed "counter-transference." In the context in which it was developed, this concept refers to the unconsciously derived attitudes and identifications which a therapist projects onto his patient. It is the natural and inescapable counterpart to the unconscious projections of the patient onto the therapist, and indeed this process of transference/counter-transference is simply a way of describing an important aspect of all human interactions. For psychoanalysis, the transference concept has central importance, because it is the patient's transferences onto the therapist which become for both the central focus of the therapeutic process. Through identification and rational exploration of that transference, the patient is brought to see the role which his unconscious is playing in affecting his everyday behavior, and the unconsciously motivated behavior thereby becomes accessible to modification. But unless the therapist's own unconscious processes, engaged by the patient's personality and behavior, are rationally accessible to the therapist, that is, unless the therapist can rationally scrutinize his countertransferences, his perceptions of the patient will be hopelessly clouded by the interweavings of his own projections and the reality presented by the patient. The therapist is thereby disabled from sensibly diagnosing and pursuing a fruitful treatment strategy for his patient.

The problems of counter-transference, however universal they may be to human relations, can be similarly disabling for sensible judicial response to child abuse and neglect cases. A judge's desire to punish the parents and remove their child, when he believes they have acted (and when in fact they have acted) hurtfully toward the child, can be as much or more a product of the judge's unconscious identifications in the transaction as his reasoned response that this individual child will best be helped by removal from these particular parents.

19 Ch. 962,1970 McKinney's Sessions Laws for New York. 
Similarly, the judge's convictions that this child should not be removed from these parents can be more a reaction to his unconscious identifications than to the reality presented by the abusing family. The situation has been described, from a psychiatrist's perspective, in this way (Steele and Pollock, 1968, p. 138):

Probably the first difficulty met by the therapist is the management of his own feelings about a parent who has hurt a small baby. Most people react with disbelief and denial, or on the other hand, with horror and a surge of anger toward the abuser... (The therapist must) gain a more useful, neutral position. ...

The capacity to gain this "more useful, neutral position" - that is, to scrutinize the fact of the counter-transference - is a hard-won therapeutic skill (Schafer, 1967). It cannot be expected that most, or even many, of those judges and court-affiliated personnel charged with the administration of child abuse and neglect laws will have had sufficient training and capacity to develop this skill. Yet without this skill, the possibility that any given judge will respond to an abusing family in a way that will accurately account for the child's needs and interests is at best wholly random, wholly dependent on the chance that this judge's unconsciously motivated perceptions happen to coincide with the real situation of the family appearing before him.

If it is important, and properly a constitutional concern - which, within limits, it is - to combat the likelihood that state officials will misperceive the need for intervention, there is one constitutional right which the Court might fruitfully put to this purpose. That would be to postulate that the parents of an allegedly abused or neglected child have a right to retained or appointed counsel. Parental counsel would promise to be one clear voice in the proceedings with an unalloyed interest in combating any state intervention. This voice would in essense combat transference-derived fantasies that home-removal was appropriate, and thus work toward providing therapeutic self-awareness for court personnel by insisting on the need to attend to the reality of the individual case at hand.

In some states, counsel is appointed to represent the child in these proceedings. ${ }^{20}$ But this role as spokesman for the "child's interest" forces counsel to resolve for himself - and always possibly in a manner dominated by his unconscious processes - whether the child's interest points to or away from home-removal. Counsel for the child is thus of no predictable assistance in forcing the administering court to confront and sort out its real as against its fantasy urgings to intervene in order to help the child.

It is, of course, true that parental counsel's insistent presence will serve to reinforce the court's fantasy, as opposed to real, convictions that no intervention is necessary. But if the judge or other administering personnel is thus inclined, it

${ }^{20}$ See footnote 3, p. 92. 
seems likely that reasons for nonintervention will be found even without counsel to suggest them. Thus it could be reasonably concluded that the presence of parental counsel would materially advance a court-derived constitutional concern - that an individualized, relatively precise judgment must precede removing a child from his parents - without unduly jeopardizing a quite reasonable contrary concern that removal will be inappropriately denied because courts will deny the reality which they in fact confront regarding the risks of harm to the child. Additionally, in order to avoid reinforcing this inappropriate denial by administering officials, the parental right to counsel might be held subject to waiver, although an excellent argument can be made against permitting waiver of counsel in these proceedings. This is an obviously rough, far from precise, accommodation of the competing interests at stake. But it is an accommodation.

In sum, the presence of counsel for the parents is intended to guard against misperceptions by administering officials. It is, however, clear that counsel's presence might work to forestall those officials from acting on wholly adequate perceptions of the need for intervention to protect the child, or might serve to withhold information, which would otherwise be available, on which officials might base an adequate judgment for intervention. This is a legitimate concern. But the court is entitled to insist that this legislative concern be met by provisions carefully tailored to it. To insist wholly on excluding counsel to meet this concern is to insist that the court unduly sacrifice the protection of its constitutionally derived interests in these proceedings.

The legitimate legislative interest in pressing administrative officials to identify and protect children in need can, however, to a substantial degree be vindicated by ensuring that those officials have ready access to a wide range of information about the child and his family. The presence of a parental advocate might be expected to combat the punitive fantasies which might lead to inappropriate removal of a particular child from his parents. The presence of extensive information about a particular child and his family might be expected to combat the wishful denials of some officials that parents are ever bad to their children. The most sensible guideline for accommodating competing judicial and legislative concerns in the administration of child abuse and neglect laws would thus be to ensure that any decision to intervene in family life is preceded by searching scrutiny, but that extensive information about the family is available to administering officials upon which they might discern whether intervention is needed.

On this ground, it would be inappropriate to extend the self-incrimination right to parents alleged to abuse or neglect their children when the purpose of the inquiry is to decide whether the child must be protected from the parent by home-removal or other means (Paulsen, 1966). Rather, administrative officials must be free to insist that parents speak fully regarding their relations with the 
child, and officials must also be free to draw negative inferences from parental resistance to full disclosures. On this ground, it would also be inappropriate to apply stringent "probable cause" standards as a prerequisite to medical examinations of the child or his parents. Particularly when dealing with younger children, and most emphatically when dealing with preverbal children, there are staggering evidentiary problems in distinguishing between those conditions of the child (whether physical or emotional) which do and those which do not indicate serious impairment of parent-child relations (Dembitz, 1969). Is this child's skull fracture accidental, as his parents now insist, or was it inflicted in parental beatings? Is this child's apparently disturbed behavior the precursor of a full-bloom psychopathology, which requires intervention into family interactions as early as possible, or is this behavior an attribute of a developmental process which will yield to "the self-healing qualities of further development ..." (Kris, 1958)? To make these distinctions in individual cases can be a complex and difficult task, even if the diagnostician has access to all conceivable information about the child's developmental history and his family's interactions with him. But without access to such information, differential diagnosis is impossible.

It is true that further development of the child will necessarily reveal what the presenting symptom foretold. But if the child's skull fracture was a symptom of a pattern of parental abuse, we can hardly afford to wait for additional confirmation if we hope effectively to protect the child. And if the child's odd behavior is a precursor of more obvious psychopathology, early intervention is equally essential to assure the possibility of successful treatment (Freud, 1965). Anna Freud correctly warns that "as knowledge stands at present, it is difficult to draw the line between prediction of pathology based on authentic danger signals, and a diffuse and indiscriminate over-anxiousness, all too easily aroused by every slight deviation from the optimal and from the norm." (Freud, 1965). It is equally true that the personnel who administer child abuse and neglect laws are even more likely than Miss Freud to have difficulty in drawing this line. But these facts do not justify withholding from diagnostic personnel the access to information upon which informed judgments might be based. It is tempting to forbid access to information as a prophylaxis against possible (or even probable) misuse of that information. But to embrace this rule as a constitutional principle is to deny the possibility that the child-protective agencies can ever improve their capacities to match performance and promise. To embrace this rule as a constitutional principle would meet the Court's concern to protect traditional values, but would unduly subordinate the legitimate interests expressed in a competing legislative judgment favoring early intervention to protect children. ${ }^{21}$

${ }^{21}$ Compare In re Vulon Children, 56 Misc. 2d 19, 288 NYS2d 203 (1968). 
The accommodation urged here - that widest access of information be assured to assist in identifying child abuse or neglect, but that rigorous scrutiny be directed at any conclusions derived from that information in part by assuring the active participation of parental counsel - might appear in some degree in conflict when considering what kind of confrontation rights will be afforded in abuse or neglect proceedings. Two objections can be raised against the proposition that all witnesses favoring state intervention must testify in open court, and be fully available for cross-examination. First, it can be argued that confidence must be guaranteed to assure either that private citizens will readily report child abuse or neglect incidents or that professional personnel will speak and write freely about the case. But such speculative gains from assuring anonymity, and the substantial likelihood that anonymity in a number of cases will merely mask spitefulness or incompetence, are clearly outweighed by the interest in full examination of the judgmental bases for removing a child from his parents or otherwise significantly intervening in the family. Second, it can be argued that public exposure of medical or psychiatric data might interfere with the prospects of subsequent treatment for the child or his parents. This is a substantial concern, but it can be accommodated on a case-by-case basis by insisting that a court be clearly convinced of the reality of therapeutic needs for nondisclosure. ${ }^{22}$

The general rule must, however, favor application of the constitutional rights to full confrontation in open court, and such confrontation must be provided at both the adjudicative and dispositional stages of child abuse and neglect proceedings. The constitutional confrontation guarantees, as applied in criminal proceedings, are at present limited to the "adjudicative" trial and have not yet been extended to sentencing proceedings to assure access, for example, to presentence reports (Remington et al., 1969). Whatever the sense of this limitation in criminal "disposition" proceedings, it is based on the logic that an adjudication that a person has committed a criminal act renders him subject to whatever variety of state intervention purposes - punishment, deterrence, rehabilitation - the state might see fit to pursue. But for child abuse and neglect proceedings, it is inconsistent with the internal logic of state laws completely to compartmentalize adjudication and disposition. The professed state purpose is to protect the child, and that purpose cannot be implemented unless the state can comparatively evaluate the parental misconduct and its potential harmfulness to the child with the available dispositional alternatives and their potential harmf ulness to the child. The unanimous outcry against and rapid abandonment of the 1969 New York heresy - which automatically linked home-removal with a finding of parental misconduct - demonstrates that state laws generally accept

22 See In re Blaine, 54 Misc. 2d 248, 282 N.Y.S. 2d 359 (1967). 
this premise (though they do not always put it into effective operation). The state abuse and neglect laws should be taken at their face on this matter, and should not be permitted to distinguish between adjudication and disposition proceedings for purposes of assuring confrontation rights.

\section{THE GAULT DECISION}

The discussion thus far compels re-examination of the Supreme Court's reasoning in Gault. If it is wrong for a court wholly to ignore the possible benefits for children in abuse and neglect proceedings that might be impeded by application of stringent procedures, it would be equally wrong to ignore these benefits and the possible harm of procedural impediments in delinquency proceedings.

There are compelling similarities between the operational contexts of neglect and delinquency laws. There is, first of all, considerable overlap between them in terms of the coercive jurisdiction each confers. The same acts which can establish a delinquency adjudication can also quite readily establish parental neglect, essentially for failure to exercise proper guidance and control as evidenced by the child's delinquent actions. The juvenile can be placed in the state's custody either as a "delinquent" or as a "neglected" child. Thus, for example, if a child must be given self-incrimination rights to protect himself against state coercion for delinquent acts, he must equally be shielded from "self-incrimination" in the operation of neglect and abuse laws which simply overlap delinquency laws. But if the criminal self-incrimination rights for the child are carried wholesale into abuse and neglect proceedings, and accompanied by the ordinary rule that any waiver must be "knowing and intelligent," 23 it is evident that court personnel could never interview a young child alleged to be neglected or abused. This consequence is inappropriately constrictive of legitimate state policy. Too much information, needed to protect the child, would be withheld from the state. This is the same reason, discussed earlier, that led to the conclusion that self-incrimination rights should be withheld from parents in neglect and abuse proceedings where child custody alone was at issue.

There is a further related reason that the self-incrimination right cannot appropriately be granted to young children who are subject to child abuse or neglect proceedings. The right must be withheld not because there is no "sanction" or "stigma" at stake for the child in these proceedings; as noted earlier, from the child's perspective at least the "remedy" of removal from his parents, however bad they may be, can quite readily appear as a desperately

${ }^{23}$ Miranda v. Arizona, 384 U.S. 436, 475 (1966). 
harsh punishment. Withholding the right follows, rather, from the proposition that the child cannot be expected to have sufficient capacity to choose between his loyalties to his parents and his personal need to be free from their mistreatment. The purpose of state intervention must be, first, to determine whether the child does in fact need to be free and, if so, to help him successfully get free. For this purpose, state officials must have access to the child - to both permit and support disloyalty to his parents when such disloyalty is necessary for the child's good. A preschool child, in particular, is peculiarly incapacitated to free himself from belief in his parents' omnipotence. He is both psychologically and practically utterly dependent (though not without influence within the family) (Freud, 1965). For this reason, it would be wrong to insist as a matter of constitutional principle that the preschool child must be given some independent role in withholding permission from the state to intervene in his life for his welfare. The grant of such independent role, as the Gault Court explicitly acknowledged, is at base the purpose of the constitutional guarantee against self-incrimination. ${ }^{24}$

With increasing age, and increasing experience outside the home, a child comes more fully and realistically to understand that he need not simply be acted upon by his environment, including his parental environment, but that he can be a self-willed actor and influence in that environment. With that growing understanding comes growing capacity to make independent choices of the kind which the self-incrimination right is intended to protect. Some delinquent behavior is, however, symptomatic of disturbances in this growth process. It cannot be said that all behavior which the community regards as "delinquent" is thus symptomatic. Nor can the delinquent behavior which is thus symptomatic be precisely quantified or readily identified at the moment a particular child comes to the attention of state authorities. But where delinquent behavior does connote this disturbance, it equally can connote an incapacity to exercise the self-incrimination right. That is, for some young and adolescent children, delinquent behavior derives from family disturbances which place the child in a bind quite similar to abuse or neglect proceedings (Freud, 1964).

This older child "knows" that he needs help and, in particular, that he needs release from an environment which makes intolerable demands on him. Yet he cannot consciously acknowledge his need for help because the psychic cost of admitting the shortcomings of his environment, and the hurtfulness of his parents toward him, seems devastating. To give this child clear, unambiguous power to resist state intervention - a power which the right against selfincrimination is intended to confer - is often virtually to assure that neither he nor anyone else will be able to acknowledge his need for help. Giving this child 
such power may be to abandon him to a fate that neither he nor the community wants. For this child, delinquency proceedings are as much a contest between his parents and state agencies - however muted and disguised that contest may appear for an older child himself accused of bad conduct - as are child abuse and neglect proceedings. And this child is as little able effectively to protect himself either against his parents or the state as the child subject to abuse or neglect proceedings (Katz, 1969).

This characterization clearly does not apply to all juvenile delinquency proceedings. Before Gault, state agencies acted as if this were a universal description. Gault argued, however, that the criminal analogue was so close, and the promise of benefit so uncertain that certain constitutional guarantees must be applied to delinquency proceedings as if children were adults. But if, in a rough way, this was Gault's instruction, that instruction is elusively oracular. For even when dealing with adults, the state has reserved much power to coerce an adult for his "best interest" and to withhold constitutional protections from adults found incompetent to exercise them (Katz, 1969). Unless Gault means that all children must be treated like adults - regardless of the state's view of their capacities or need for coerced assistance - the Gault instruction gives little clear direction.

The technique for accommodating the competing demands of the criminal and civil procedural models, described earlier for child abuse and neglect laws, can be easily applied to justify all but one of the specific procedural rights conferred by the Gault Court and subsequent Supreme Court action. Just as in abuse and neglect laws, Gault's insistence on appointed counsel to represent the child, on clear advance notice, and on confrontation of all witnesses at the delinquency hearing are essential to ensure a rigorous testing of the basis of any claim for beneficial state intervention. The recent extension of Gault to require proof "beyond a reasonable doubt" in delinquency proceedings ${ }^{25}$ is similarly justifiable. And, for the reasons discussed regarding abuse and neglect laws, it would be wrong to limit these procedural rights to those proceedings in which the child is charged with conduct which, for an adult, would be a crime. For whatever reason the state chooses to force assistance on an unwilling juvenile, these procedural guarantees are essential to assure a reasonable likelihood that benefit will result, and thus to justify the withholding of whatever other criminal procedure guarantees the state might properly consider to interfere with its beneficial purposes.

But Gault's bestowal of the right against self-incrimination in delinquency proceedings raises more complex questions. Gault, moreover, insisted that

25 In re Winship, 397 U.S. 358 (1970). 
Mirand $^{26}$ also applied in full force to the delinquency proceedings, ${ }^{27}$ so that the right to appointed counsel came to the juvenile at his earliest contact with state authorities. If we ignore for the moment the likely practical consequences of this bestowal of self-incrimination rights, and focus rather on the idealized imagery which shines through the Court's opinions, the juvenile will be warned at the moment state officials contact him that he need not speak and that he can have appointed counsel. If he chooses either to remain silent or to have counsel, all further private communication between the juvenile and court personnel will end. Moreover, the slightest hesitation by the juvenile in response to the Miranda warnings will be construed as an invocation of the rights to silence and to an attorney. In short, private conversation between the juvenile and court personnel about the juvenile's alleged actions will be impossible unless eagerly initiated by the juvenile himself.

If this image were the practical reality, it would obviously make it impossible for the state to make contact with, and effectively offer assistance to, that class of juveniles described earlier as lacking capacity for exercising the self-incrimination right. These juveniles' inability to acknowledge their need for release from their present environment, their incapacity to ask for help by "choosing to confess," can only be remedied by confidential, confidence-giving, prodding, and thus subtly coercive conversation with empathetic, well-trained court personnel (Schafer, 1959). Conferring the self-incrimination right can mean that these juveniles will be lost to whatever help the state might offer, just as provision of the self-incrimination right in child abuse and neglect proceedings would make it prohibitively difficult to develop information by which the child's need for protection could be identified. On what basis did the Court override a contrary legislative judgment that it was more important to have access to these juveniles than to give the self-incrimination protection to others?

The Gault Court appears to adopt three arguments - first, that little benefit is in fact likely to come to any juvenile from the staff and facilities currently available; second, that privately induced confessions are likely to be antitherapeutic when followed by coercive sanction; and third, that many juvenile "confessions" are in fact notoriously unreliable. ${ }^{28}$ The Court's second argument has particular strength. While it is true that granting power to many youths to forestall state intervention can disable them from asking the help they need, it is also true that withholding power to resist intervention can be equally

${ }^{26}$ Miranda v. Arizona, 384 U.S. 436 (1966).

27387 U.S. at $26,55$.

${ }^{28}$ See 387 U.S. at $21-23,51-55$. 
destructive of therapeutic goals. If help is seen as merely forced, rather than asked and needed, the coerced youth is likely to lock himself into a power struggle with yet another hostile environment. Any known therapeutic technique for changing self-destructive delinquent behavior cannot succeed unless the active collaboration and cooperation of the youth himself is secured (Council of Am. Psychiat. Assoc., 1967; Katz, 1969). Thus, if the Court is concerned to ensure that the reality of therapeutic benefit match its promise in juvenile dispositions, its most reliable ultimate indicator is the willingness of the juvenile to accept the offered treatment. Guaranteeing the right against self-incrimination can effectively serve this end.

But however true all of the Court's arguments may be, they do not establish that the formal imagery of the self-incrimination guarantee should be imposed in an effort to keep court personnel always at arms' length from an alleged delinquent juvenile. Rather, a more finely tuned adjustment of competing goals could be made by permitting early and extensive staff access to the juvenile, but greatly restricting subsequent uses of the "fruit" of that early access. This alternative formulation is not necessarily inconsistent with Gault. It is not, however, clearly envisioned or invited by the Court, but instead is discouraged. Under Gault, court personnel could refuse to permit a juvenile access to an attorney, and question him at length, so long as they are willing to be disabled, by the exclusionary rule, from later using any information thus gathered to impose an unwanted disposition on the juvenile. The dogma of the exclusionary rule is such, however, that any self-respecting court official could not admit using it in this way. Rather, the exclusionary rule is supposed to operate as an incentive to "do good," and as the Gault Court appears to have defined "good" in this context, it is that court officials should not have easy access to uncounseled juveniles.

The Court should have attempted to apply the self-incrimination guarantee to juvenile court proceedings in a way which would not disable court personnel from exerting confidential pressure against a juvenile who could not otherwise be helped, and yet which would forestall the abuses to which this easy access might be put. The technique for doing this was obviously at hand, if the Court simply were to have viewed the exclusionary rule as granting permission for denying the right to silence and to counsel, rather than as a device to ensure that these rights were never denied. By this means, the Gault Court could have acknowledged the quite legitimate state interest in securing confidential access to juveniles in order to persuade them to accept treatment, while protecting the countervailing interest of the resisting juvenile by ensuring that if state persuasion fails, the information gathered during the confidential interviews could not be used to coerce the juvenile into an unwilled treatment. If the process of state persuasion fails, we have a quite reliable indicator that little good is likely to come to the juvenile from state intervention (though punitive 
intervention to protect the community may still obviously be warranted). But if, as is the case under Gault, the state is deprived of an easy and openly acknowledged opportunity to persuade the juvenile to accept treatment, we cannot be certain that all who might have benefited from whatever therapeutic treatment was available would in fact have been identified. It is clear, as Gault posits, that the state and many juveniles are likely adversaries in delinquency proceedings. It is not clear that all juveniles must be so regarded from the beginning of their encounter with the state.

The exclusionary rule, by demanding suppression of all "fruits of the poisonous tree," can operate so that the state is unlikely to have any coercive hold on a juvenile who is confidentially questioned and resists later cooperation (Pitler, 1968). State officials would be unwilling to run this risk for some juveniles who have allegedly committed offenses which are gravely injurious to others or greatly offensive to the community. But for such juveniles, court officials would obviously be free - under the more permissive reading of the Gault exclusionary rule which is suggested here - to forego their option for confidential persuasion, and to deal with the juvenile at arms' length from the first encounter. The confidential persuasion option would most likely be exercised in those cases where it is not clearly essential for community safety that the juvenile be detained against his will. Casual "joy-riding" car theft, minor narcotics offenses, petty property thefts, or minor assaults among acquaintances are likely examples, in addition to such "noncriminal" offenses as truancy or "being habitually beyond parental control." Such matters are the great bulk of the jurisdiction of juvenile courts in this country (Morris and Hawkins, 1969).

The preceding discussion speaks to the idealized imagery of Gault. In its practical impact, however, it is clear that much room is left for coercive pressure against juveniles because Gault held that the juvenile could waive his right to silence without any prior advice from counsel, his parents, or any third party. ${ }^{29}$ This waiver possibility permits police, or other juvenile court officials, to effect rapid, low-visibility coercions, and thereby confidentially to interrogate. ${ }^{30}$ But court officials cannot openly, honestly, and unashamedly interrogate. Gault thus preserves nothing of benefit for the juvenile but only assures opportunity for abuse. The sensible benefits from "pressure to confess" exerted on a juvenile can come only if some time can be spent in relatively relaxed confidential communication where resistances can be explored, contradictions in attitudes

29387 U.S. at 55 .

30

See Note, "Interrogation in New Haven: The impact of Miranda." Yale Law J. 76:1519 (1967); Note, "A postscript to the Miranda project: Interrogation of Draft Protesters." Yale Law J. 77: 300 (1967). 
can be identified, and confidences can be built. Gault does not invite this opportunity.

But Gault does hold open the possibility for state legislature to remedy its failure clearly to legitimate early confidential access to juveniles by court officials. State legislatures can adopt immunity statutes for juvenile court proceedings - as frequently has been done for adult criminal proceedings $^{31}$ - which can permit court officials to require that a juvenile forego his rights to silence and to counsel during questioning in return for immunity from prosecution for the offense about which the juvenile is questioned. Though such statute for juveniles might appear impolitically "soft on delinquents," it would respond to the reality that coercive sanctions against juveniles are unlikely to. have therapeutic benefit. But precisely because of the public unpopularity of this stance, it is unfortunate that the Court did not understand the need to legitimate such conduct by juvenile court authorities rather than leaving the question to state legislative action.

\section{THE WYMAN DECISION}

Gault erred by discounting the beneficial uses of coercion. Wyman, in refusing any procedural safeguards to ensure that welfare home visits would have some beneficial purpose, erred more egregiously by ignoring the potential for abuses in coercion. The Wyman Court should have imposed a warrant requirement to give contemporary vindication to the traditional personal privacy values of the Fourth Amendment. ${ }^{32}$ But, as with abuse and neglect laws and delinquency laws, the Court should not have applied the constitutional warrant requirement wholesale to the welfare home visit. To do so would unduly impede a legitimate beneficent purpose of that visit. If the Fourth Amendment is automatically applied, no warrant could be issued unless welfare officials first showed that they had "probable cause" - that is, highly persuasive and individualized proof - to support the necessity for the visit. Thus, if a caseworker sought a warrant based on a belief that a welfare parent was abusing her child, the caseworker would need to support this belief with compelling evidence. This application of the "probable cause" standard would restrict

31 See Note, "State immunity statutes in constitutional perspective." Duke Law J. 311 (1968); Note, "Immunity statutes and the Constitution." Colum. Law Rev. 68: 959 (1968).

32 The Fourth Amendment to the Constitution provides this: "The right of the people to be secure in their persons, houses, papers, and effects, against unreasonable searches and seizures, shall not be violated, and no Warrants shall issue, but upon probable cause, supported by $\mathrm{Oath}$ or affirmation, and particularly describing the place to be searched, and the persons or things to be seized." 
investigations as sharply, and as much to the detriment of children, as would application of this standard to preliminary examinations in child abuse and neglect proceedings. Relations between parents and, in particular, preschool children have too little ready visibility to expect that children can be adequately protected by generally requiring "probable cause" to believe injury before state authorities can examine children or their parents against the parents' will.

The argument for a lower proof standard for state child protective purposes is not derived from anything peculiar to the welfare program. Rather the argument is drawn from considering the needs of state child-protective programs generally. It is true, however, that child-protective programs are most rigorously carried out against welfare recipients, and thus a rule which generally permits easy state investigation of parent-child relationships will fall with particular force on welfare families. There is some slight reason to believe that welfare families as a group, for whatever cause, are more likely than other families to warrant state intervention to protect young children (Gil, 1970, pp. 112-114, 139). But this evidence is not strong enough to establish compellingly persuasive differences between welfare and other families. The state could not satisfy a substantial burden of proof in order to justify concentrating its child-protective investigators on welfare families, if this showing were required.

But would a court be justified in imposing such a proof burden in this matter? The consequences of such burden would be that the state could avoid a "probable cause" showing for child-protective investigations only when its investigations were randomly distributed throughout its population or, of course, covered all of its population. The predictive tools for identifying children in need of protection from their parents for whatever reason are utterly inadequate to justify preselecting any segment of the population for special attention (Gil, 1970, pp. 125-132 and Chap. II). It might be argued that this court demand for perfection would in fact not interfere with any legitimate state purpose on the ground that any deployment of its child-protective investigators is essentially random, whether focused on welfare families or elsewhere, and thus the same number of children needing protection is likely to be found wherever state investigators look. But this argument ignores the fact that there is already a welfare bureaucracy staffed with investigators who have regular contact for many purposes with an identifiable clientele. This investigative staff cannot be diverted to random checks of all families for child-protective purposes. If a court were to require such randomization as the price for avoiding a "probable cause" barrier, the option would not likely be pursued by any state agency. And thus there would be a net loss of children in need of care who would in practice be found.

All of those "lost" children would be from welfare families. But is it not clear that the interests of welfare recipients generally in resisting empirically unsupported, and to some degree stigmatizing, state identification as peculiarly 
"child-neglect-prone" should outweigh the interests of those needy children among them in securing protection from harmful parents. The interests of both welfare recipients and needy welfare children are substantial and are in conflict. The Wyman Court simply neglected the parents' interests and opted for the interests of the children. A more persuasive resolution here - as elsewhere in the matters discussed by this article - is to mediate the conflicting interests.

\section{REFERENCES}

Bowlby, J. (1965). Child Care and the Growth of Love. Penguin Books, Inc,, Baltimore.

Council of Am. Psychiat. Assoc. (1967). Position statement on the question of adequacy of treatment. Am. J. Psychiat. 123: 1458, 1459.

Dembitz, N. (1969). Child abuse and the law - fact and fiction. Rec. Assoc. Bar City N.Y. 34: 613,616 .

Fanshel, D. (1971). The exit of children from foster care: An interim research report. Child Welfare 1(2): 65,71 .

Freud, A. (1964). The Psychoanalytic Treatment of Children. Schocken Books, Inc., New York.

Freud, A. (1965). Normality and Pathology in Childhood. International Universities Press, New York.

Freud, A. (1967). The ego and the mechanisms of defense. In Katz, J., Goldstein, J., and Dershowitz, A. (eds.), Psychoanalysis, Psychiatry and Law, Free Press of Glencoe, New York, pp. 144-147.

Gil, D. (1970). Violence Against Children. Harvard Univ. Press, Cambridge.

Gill, M. (1967). Psychoanalysis and exploratory psychotherapy. In Katz, J., Goldstein, J., and Dershowitz, A. (eds.), Psychoanalysis, Psychiatry and Law, Free Press of Glencoe, New York, pp. 669-671.

Katz, J. (1969). The right to treatment - an enchanting legal fiction. Univ. Chicago Law Rev. 36: 755, 770-771.

Kris, E. (1958). Cited by Freud, A., in Child observation and prediction of development. Psychoanal. Study Child 13: 92, 98.

Morris, N., and Hawkins, G. (1969). The Honest Politician's Guide to Crime Control. Univ. Chicago Press, Chicago.

Paulsen, M. (1966). The legal framework for child protection. Columbia Law Rev. 66: 679, 680-686, 693-703.

Pitler, R. (1968). The 'fruit of the poisonous tree' revisited and shepardized. Calif. Law Rev. 56: 579 .

Remington, F., Newman, D., Kimball, E., Melli, M., and Goldstein, H. (1969). Criminal Justice Administration. Bobbs-Merrill Co., Indianapolis.

Schafer, R. (1959). Generative empathy in the treatment situation. Psychoanal. Quart. 28: 342 .

Schafer, R. (1967). On the nature of the therapeutic relationship. In Katz, J., Goldstein, I., and Dershowitz, A. (eds.), Psychoanalysis, Psychiatry and Law, Free Press of Glencoe, New York, pp. 722-723.

Steele, B., and Pollock, C. (1968). A psychiatric study of parents who abuse infants and small children. In Helfer, R.E., and Kempe, H. (eds.), The Battered Child, University of Chicago Press, Chicago, pp. 103, 144.

Terr, L., and Watson, A. (1968). The battered child rebrutalized: Ten cases of medical-legal confusion. Am. J. Psychiat. 124: 1432. 